\title{
TAKSONOMI PEMBELAJARAN DAN PENILAIAN HASIL BELAJAR BERBASIS TRIKAYA
}

\author{
I Wayan Subagia ${ }^{1}$, I Gusti Lanang Wiratma ${ }^{2}$ \\ 1,2Jurusan Pendidikan Fisika FMIPA, Universitas Pendidikan Ganesha \\ Singaraja, Indonesia \\ e-mail: aigabus@yahoo.co.id
}

\begin{abstract}
Abstrak
Penelitian ini bertujuan untuk mengembangkan taksonomi dan penilaian hasil belajar berbasis kompetensi. Perumusan taksonomi tersebut dilakukan melalui penelitian pengembangan dengan lima tahapan pokok, yaitu pengumpulan informasi, perencanaan, perumusan gagasan model taksonomi, pengujian model oleh ahli, dan penyempurnaan model taksonomi. Hasil penelitian ini berupa rumusan taksonomi penilaian hasil belajar berbasis kompetensi yang selanjutnya diberi nama Taksonomi Trikaya. Taksonomi Trikaya terdiri atas tiga domein, yaitu domein pikiran (manacika), perkataan (wacika), dan perbuatan (kayika). Domein pikiran teridiri atas: 1) berpikir faktual, 2) berpikir positif, 3) berpikir rasional logis, 4) berpikir kritis, dan 5) berpikir kreatif inovatif. Domein perkataan tediri atas: 1) berbicara santun, 2) berbicara faktual, 3) berbicara rasional logis, 4) berbicara sistematis, dan 5) berbicara komunikatif. Domein perbuatan terdiri atas: 1) berbuat sopan, 2) berbuat patuh, 3) berbuat jujur, 4) berbuat yakin, dan 5) berbuat kreatif inovatif.
\end{abstract}

Kata kunci: taksonomi, hasil belajar, trikaya.

\begin{abstract}
The aim of this research was to develop taxonomy of instruction and assessment for learning achievement. This research was conducted by using research and development $(R$ \& D) model involving five steps, namely: gathering information, planning, formulation of model of taxonomy, examination model, and improvement model. The result of this research was a model of assessment taxonomy called Taxonomy Trikaya. The Taxonomy Trikaya consisted of three domains, namely: thinking, speech, and action. The domain of thinking consisted of: 1) factual thinking, 2) positive thinking, 3) rational logic of thinking, 4) critical thinking, and 5) creative innovative thinking. Domain of speech consisted of: 1) polite speech, 2) factual speech, 3) rational logic of speech, 4) systematic speech, and 5) communicative speech. Domain of action consisted of: 1) polite action/behaviour, 2) obey rules, 3) be honest, 4) confidence, and 5) creative innovative action.
\end{abstract}

Keywords: taxonomy, learning achievement, trikaya. 


\section{PENDAHULUAN}

Semenjak digulirkannya regulasi pelaksanaan kurikulum berbasis kompetensi yang diimplementasi dalam bentuk pelaksanaan Kurikulum Tingkat Satuan Pendidikan (KTSP), berbagai masalah dalam pengelolaan pembelajaran bermunculan. Hal tersebut sebagian disebabkan oleh kemampuan adaptabilitas dan sikap resistan para guru terhadap perubahan (Subagia, 2004; 2006). Salah satu perubahan mendasar yang dilakukan dalam implementasi kurikulum berbasis kompetensi adalah perubahan orientasi terhadap tujuan pembelajaran dan penilaian hasil belajar. Tujuan pembelajaran didefinisikan dalam bentuk kompetensi yang diharapkan dimiliki peserta didik setelah melalui proses pembelajaran. Kompetensi didefinisikan sebagai penguasaan pengetahuan, keterampilan, sikap, dan nilai yang dioperasionalkan dalam kehidupan sehari-hari (Mulyasa, 2007). Berdasarkan pengertian tersebut, dapat dinyatakan bahwa hasil belajar hendaknya merupakan perubahan kemampuan yang teramati, baik kemampuan berupa pengetahuan, keterampilan, sikap, maupun nilai yang berubah sesuai dengan perkembangan jaman dan ilmu pengetahuan serta teknologi. Oleh karena itu, penilaian hasil belajar perserta didikpun hendaknya mengalami perubahan cara, baik cara asesmennya maupun cara penilaiannya.

Selama ini, cara asesmen dan penilaian hasil belajar lebih banyak dikembangkan berdasarkan gagasan penilaian hasil belajar yang dikemukakan oleh Benyamin S. Bloom, dan kawan-kawan yang dikalangan dunia pendidikan dikenal dengan Taksonomi Bloom. Hasil belajar diklasifikasikan dalam tiga domein (ranah), yaitu: domein kognitif, afektif, dan psikomotor. Ketiga domein tersebut dijabarkan secara lebih rinci menjadi bagian-bagian yang dijadikan acuan pengembangan instrumen penilaian hasil belajar. Domein kognitif meliputi hasil-hasil berpikir yang digradasi mulai dari mengingat, memahami, menerapkan, menganalisis, mensintesis, dan mengevaluasi. Domein afektif meliputi penerimaan, jawaban atau reaksi, penilaian, organisasi, dan internalisasi. Domein psikomotor meliputi gerakan refleks, keterampilan gerakan dasar, kemampuan perseptual, keharmonisan atau ketepatan, gerakan keterampilan kompleks, dan gerakan ekspresif dan interpretatif (Dimyati \& Mudjiono, 2002).

Pengalaman empirik menunjukkan bahwa guru-guru banyak mengalami masalah ketika disuruh untuk memetakan kompetensi hasil belajar ke dalam indikatorindikator hasil belajar yang dirumuskan berdasarkan Taksonomi Bloom. Misalnya, apabila suatu tujuan pembelajaran dalam mata pelajasan kimia SMA, dirumuskan, "mendeskripsikan kekhasan atom karbon dalam membentuk senyawa hidrokarbon," maka pertanyaannya adalah apa saja pengetahuan yang harus dimiliki siswa sebagai jaminan bahwa mereka mampu mendeskripsikan kekhasan atom karbon. Dalam merumuskan indikator penilaian kompetensi tersebut, para guru mengalami kesulitan, apakah hanya tingkat kognitif dalam kategori C1, C2, C3, atau jenjang kognitif yang lainnya yang sesuai digunakan untuk merumuskan indikator kemampuan "mendeskripsikan." Hal ini menunjukkan bahwa penggunaan Taksonomi Bloom dalam pengkategorian hasil belajar yang dirumuskan dalam bentuk kompetensi tidaklah mudah. Apabila dihubungkan dengan ide kompetensi yang merupakan

Jurnal Pendidikan Indonesia | 41 
kemampuan komprehensif yang terdiri atas pengetahuan, keterampilan, sikap dan nilai, maka terlihat bahwa penilaian yang dilakukan berdasarkan domein kognitif Bloom kurang tepat karena penilainpenilaian tersebut bersifat parsial.

Berdasarkan fenomena empirik dan teoretis tersebut, maka dalam penelitian ini dikembangkan taksonomi lain untuk menilai hasil belajar. Pengembangan taksonomi ini dilakukan berdasarkan kajian empirik dan teoretis terhadap nilai-nilai kearifan lokal masyarakat Bali yang berhubungan dengan penilaian kemampuan seseorang. Salah satu nilai-nilai kearifan lokal masyarakat Bali yang dijadikan acuan dalam pengembangan taksonomi baru ini adalah ajaran Trikaya Parisudha.

Trikaya Parisudha merupakan salah satu ajaran agama Hindu yang berisikan tentang kebajikan dalam berbuat. Perbuatan yang dimaksud dikelompokkan menjadi tiga, yaitu perbuatan dalam tataran pikiran yang disebut dengan kemampuan berpikir (manacika), perbuatan dalam tataran perkataan yang disebut dengan kemampuan berbicara (wacika), dan perbuatan dalam tataran perilaku atau tingkah laku yang disebut dengan kemampuan berbuat (kayika). Secara konseptual, ketiga jenis perbuatan tersebut merupakan satu kesatuan yang terbangun secara hirarki mulai dari pikiran diteruskan ke perkataan dan diwujudkan dalam perbuatan.

Walaupun pikiran tidak bisa diamati, namun diyakini bahwa, baik perkataan maupun perbuatan, keduanya bersumber pada pikiran. Pikiran yang benar akan memberikan dasar untuk berbicara yang benar dan berbuat yang benar. Demikian juga halnya dengan perkataan yang benar, umumnya, akan menjadi pemandu untuk berbuat yang benar. Sebagian dari pikiran diwujudkan dalam kata-kata dan perbuatan, sebagian kata-kata diwujudkan dalam perbuatan. Kemampuan seseorang dapat diketahui melalui hasil pemikirannya, perkataannya, dan perbuatannya. Oleh karena itu, pikiran, perkataan, dan perbuatan digunakan sebagai domein penilaian kompetensi seseorang dalam bentuk taksonomi.

Ajaran kebajikan yang dikenal dengan Trikaya Parisudha dimuat dalam kitab Sarasamuscaya (Parisada Hindu Dharma, 1979). Kitab tersebut merupakan salah satu kitab suci agama Hindu yang ada di Indonesia. Dalam sloka 79 - 82 kitab tersebut dijabarkan tentang hal-hal yang tidak boleh dilakukan dalam kehidupan sehingga hidup di dunia dapat mencapai kesejahteraan dan kedamaian (moksartham jagathitaya). Dalam sloka tersebut dinyatakan ada 10 perbuatan yang harus dilakukan, yaitu bersumber dari pikiran dan perbuatan masing-masing tiga perbuatan, serta empat perbuatan bersumber dari perkataan. Pikiran harus dikendalikan dengan tidak berpikir dengki dan iri hati terhadap milik orang lain, tidak berpikir untuk menyakiti makhluk apapun, dan tidak mengingkari kebenaran ajaran karma phala. Ajaran karma phala merupakan sradha ketiga dari lima dasar keyakinan agama Hindu yang dikenal dengan pancasradha. Perkataan harus dikendalikan dengan tidak berkata-kata kotor, tidak berkata-kata kasar, tidak berkata-kata mengandung fitnah, dan tidak berkata-kata bohong. Perbuatan harus dikendalikan dengan tidak mencuri, tidak membunuh, dan tidak berzinah.

Pikiran dengki dan iri hati terhadap milik orang lain akan berpotensi untuk menyesatkan perkataan dan perbuatan dengan berkata-kata kotor, kasar, fitnah, dan bohong serta berbuat mencuri, 
membunuh dan berzinah yang semua dapat mengancam keselamatan jiwa dan raga. Sebaliknya, pikiran yang tidak marah terhadap makhluk apapun akan menuntun pengembangan rasa kasih sayang terhadap semuai makhluk hidup, berbicara secara santun dan lemah lembut, menggunakan kata-kata yang mendatangkan kedamaian, berperilaku sopan, menghargai orang lain, dan taat kepada peraturan yang berlaku. Pikiran yang tidak mengingkari kebenaran ajaran karma phala akan menuntun untuk berpikir kritis yang dapat diwujudkan dalam bentuk berpikir sebab akibat (kausalistik), berpikir prediktif, dan berpikir antisipatif.

Kata-kata kotor dan kata-kata kasar berupa cacian atau makian terhadap orang lain tidak akan membuat orang lain menjadi senang, sebagai akibatnya cenderung akan menimbulkan balasan kata-kata yang kurang lebih sama, dalam arti kata-kata yang juga tidak menyenangkan. Hal tersebut sangat berpotensi diikuti oleh perbuatan yang tidak menyenangkan hingga pembunuhan. Kata-kata fitnah dan kata-kata bohong adalah kata-kata yang sangat kejam karena tidak mengandung kebenaran. Dalam ungkapan, sering, dinyatakan bahwa "fitnah lebih kejam dari pembunuhan." Kebiasaan memfitnah dan berbohong cenderung akan diikuti oleh perkataan yang sama pada waktu-waktu berikutnya, sehingga dinyatakan bahwa kebohongan cenderung akan diikuti oleh kebohongan berikutnya. Akibatnya, akan menggiring seseorang untuk berbohong selamanya.

Perbuatan mencuri adalah berbuatan melanggar hukum. Konsekuensi dari mencuri adalah menerima hukuman sesuai dengan jenis dan kapasitas pencurian yang dilakukan. Perbuatan membunuh adalah perbuatan yang tidak dilandasi oleh perasaan kasih sayang.
Perbuatan tersebut adalah perbuatan yang tidak menghargai hak azasi manusia. Pembunuhan terhadap manusia merupakan pelanggaran hak azasi manusia (HAM) karena hidup merupakan salah satu hak azasi manusia. Perbuatan berzinah merupakan perbuatan yang tidak menghargai nilai-nilai atau norma-norma kehidupan. Perbuatan tersebut cenderung mengakibatkan ketidaknyamanan hidup.

Di samping konseptual teoretis ajaran Trikaya Parisudha yang telah diuraikan di atas, pengembangan model taksonomi penilaian hasil belajar tersebut juga didasari oleh penelitian yang telah dilakukan sebelumnya. Pertama, penelitian tentang cara-cara penilaian kemampuan seseorang di dalam organisasi tradisional masyarakat Bali. Dalam penelitian tersebut diungkapkan jenis-jenis penilaian dan caracara penilaian yang dilakukan, baik oleh pimpinan organisasi terhadap bawahannya maupun penilaian bawahan terhadap anggota organisasi. Di samping itu, juga diungkatkan orang-orang yang mesti terlibat dalam penilaian terhadap seseorang adalah keluarga, teman kerja, atasan, dan diri sendiri (Subagia \& Wiratma, 2009). Kedua, penelitian tentang kemampuan kepala sekolah dan guru dalam melaksanakan tugas yang dinilai secara silang: kepala sekolah dinilai oleh guru dan guru dinilai oleh kepala sekolah. Hasil penelitian ini juga mengungkapkan cara-cara penilaian yang digunakan untuk menilai kemampuan seseorang (Subagia \& Wiratma, 2010). Kedua hasil penelitian tersebut dapat dilihat sebagai implementasi ajaran Trikaya Parisudha di masyarakat dalam konteks kekinian. Oleh karena itu, dapat dinyatakan bahwa pengembangan model taksonomi penilaian hasil belajar berbasis kompetensi berdasarkan nilai-nilai kearifan lokal

Jurnal Pendidikan Indonesia | 43 
masyarakat Bali yang diformulasikan dalam penelitian ini dikembangkan berdasarkan landasan teoretis ajaran kebajikan dan pengalaman empiris masyarakat Bali.

\section{METODE PENELITIAN}

Penelitian ini merupakan penelitian pengembangan yang dilakukan dalam lima tahapan. Menurut Borg \& Gall (1989) penelitian pengembangan dapat dilakukan dalam enam tahapan, yaitu: 1) tahap pengumpulan informasi penelitian, 2) tahap perencanaan, 3) tahap perumusan hasil awal, 4) tahap pengujian lapangan awal, 5) tahap penyempurnaan hasil, dan 6) tahap pengujian lapangan akhir. Tahap pengumpulan informsi awal dan tahap perencanaan telah dilakukan pada penelitian tahun pertama dan kedua. Pada penelitian ini dilakukan tiga tahapan berikutnya, yaitu: tahap pengembangan model taksonomi, tahap pengujian model taksonomi, dan 3) tahan penyempurnaan model taksonomi. Dalam hal ini, belum dilakukan tahap pengujian lapangan secara luas.

Tahap pengujian model taksonomi dilakukan melalui penilaian ahli (expert judgment) dalam bentuk penilaian naskah dokumen yang dilakukan secara kuantitatif dan kualitatif dan dilanjutkan dengan diskusi panel yang diikuti oleh guru SD, SMP, SMA, dan SMK, serta dosen UNDIKSHA yang jumlahnya 100 orang. Ahli yang dilibatkan dalam penelitian ini adalah sebanyak tujuh orang terdiri atas empat orang guru besar UNDIKSHA, satu guru besar UNUD, satu orang guru besar IHDN Denpasar, dan satu orang doktor IHDN Denpasar. Para ahli memberikan penilaian dan saran/masukan untuk setiap aspek dari rumusan taksonomi yang terdiri atas konsepsi teoretis taksonomi, rumusan domein, dan rumusan setiap aspek penilaian domien masingmasing.

\section{HASIL DAN PEMBAHASAN}

Hasil penelitian ini berupa rumusan taksonomi penilaian hasil belajar berbasis kompetensi berdasarkan nilai-nilai kearifan lokal masyarakat Bali yang selanjutnya diberi nama Taksonomi Trikaya. Nama tersebut diberikan karena nilai-nilai kearifan lokal masyarakat Bali yang digunakan sebagai dasar pengembangan taksonomi adalah ajaran Trikaya Parisudha. Trikaya Parisudha merupakan salah satu ajaran agama Hindu yang berisikan tentang nilainilai kebajikan dalam berbuat. Menurut ajaran Trikaya Parisudha, perbuatan dapat dikelompokkan menjadi tiga, yaitu: berpikir (manacika), berbicara (wacika), dan berbuat (kayika) (Sudharta \& Atmaja, 2001).

Taksonomi Trikaya yang dirumuskan sebagai hasil penelitian dideskripsikan dalam dua bagian, yaitu: 1) konsepsi teoretis Taksonomi, dan 2) rumusan domein Taksonomi. Rumusan domein Taksonomi Trikaya terdiri atas aspek penilaian dan indikator penilaian untuk tiap-tiap aspek.

\section{Konsepsi Teoretis Taksonomi Trikaya}

Secara filosofis, taksonomi Trikaya diturunkan dari ajaran Trikaya Parisudha yang merupakan salah satu ajaran agama Hindu yang mengajarkan tentang kebajikan dalam berbuat. Perbuatan yang dimaksud dikelompokkan menjadi tiga, yaitu perbuatan dalam tataran pikiran yang disebut dengan kemampuan berpikir (manacika), perbuatan dalam tataran perkataan yang disebut dengan kemampuan berbicara (wacika), dan berbuatan dalam tataran perilaku atau tingkah laku yang disebut dengan kemampuan berbuat (kayika). Secara 
konseptual, ketiga jenis perbuatan merupakan satu kesatuan yang terbangun secara berjenjang (hirarki) mulai dari pikiran diteruskan ke perkataan dan diwujudkan dalam bentuk perbuatan. Walaupun pikiran tidak bisa diamati, namun diyakini bahwa, baik perkataan maupun perbuatan, keduanya bersumber pada pikiran. Pikiran yang benar akan memberikan dasar untuk berbicara yang benar dan berbuat yang benar. Demikian juga halnya dengan perkataan yang benar, umumnya akan menjadi pemandu untuk berbuat yang benar. Sebagian atau seluruh pikiran akan diwujudkan dalam kata-kata dan perbuatan, sebagian atau seluruh kata-kata akan diwujudkan dalam perbuatan. Kemampuan atau kompetensi seseorang dapat diketahui melalui hasil pemikirannya, perkataannya, dan perbuatannya. Oleh karena itu, pikiran, perkataan, dan perbuatan digunakan sebagai domein penilaian kompetensi atau kemampuan seseorang dalam bentuk taksonomi dengan nama Taksonomi Trikaya.

Ajaran kebajikan yang dikenal dengan Trikaya Parisudha dimuat dalam kitab Sarasamuscaya yang merupakan salah satu kitab suci agama Hindu yang ada di Indonesia. Dalam sloka 79 - 82 dijabarkan tentang hal-hal yang tidak boleh dilakukan dalam kehidupan sehingga hidup di dunia dapat mencapai kesejahteraan dan kedamaian (moksartham jagathitaya). Dalam sloka tersebut dinyatakan ada 10 perbuatan yang harus dilakukan, masingmasing tiga bersumber dari pikiran dan perbuatan, serta empat bersumber dari perkataan. Pikiran harus dikendalikan dengan tidak berpikir dengki dan iri hati terhadap milik orang lain, tidak berpikir untuk menyakiti makhluk apapun, dan tidak mengingkari kebenaran ajaran karma phala.
Ajaran karma phala merupakan salah satu dari lima dasar keyakinan (pancasradha) agama Hindu yang menyatakan "Percaya terhadap hukum karma phala" (Maswinara, 1996, Punyatmadja, 1976) Perkataan harus dikendalikan dengan tidak berkata-kata kotor, tidak berkata-kata kasar, tidak berkata-kata mengandung fitnah, dan tidak berkata-kata bohong. Perbuatan harus dikendalikan dengan tidak mencuri, tidak membunuh, dan tidak berzinah.

Pikiran dengki dan iri hati terhadap milik orang lain akan berpotensi untuk menyesatkan perkataan dan perbuatan dengan berkata-kata kotor, kasar, fitnah, dan bohong serta berbuat mencuri, membunuh dan berzinah yang semua dapat mengancam keselamatan jiwa dan raga. Sebaliknya, pikiran yang tidak marah terhadap makhluk apapun atau pikiran kasih sayang akan menuntun pengembangan rasa kasih sayang yang akan menuntun berbicara secara santun, lemah lembut, menggunakan kata-kata yang mendatangkan kedamaian serta perbuatan yang sopan, menghargai orang lain dan taat kepada peraturan yang berlaku. Pikiran yang tidak mengingkari kebenaran ajaran karma phala akan menuntun untuk berpikir kritis yang dapat diwujudkan dalam bentuk berpikir kausalistik, berpikir prediktif, dan berpikir antisipatif.

Kata-kata kotor dan kata-kata kasar berupa cacian atau makian terhadap orang lain akan membuat orang lain menjadi tidak senang, sebagai akibatnya cenderung akan menimbulkan balasan kata-kata yang kurang lebih sama, dalam arti kata-kata yang juga tidak menyenangkan juga. Hal tersebut sangat berpotensi diikuti oleh perbuatan yang tidak menyenangkan hingga pembunuhan. Kata-kata fitnah dan kata-kata bohong adalah kata-kata yang sangat kejam

Jurnal Pendidikan Indonesia | 45 
karena tidak mengandung kebenaran. Dalam ungkapan bahasa Indonesia sering dinyatakan bahwa "fitnah lebih kejam dari pembunuhan." Kebiasaan memfitnah dan berbohong cenderung akan diikuti oleh perkataan yang sama pada waktu-waktu berikutnya, sehingga dinyatakan bahwa kebohongan cenderung akan diikuti oleh kebohongan berikutnya. Akibatnya, akan menggiring untuk berbohong selamanya.

Perbuatan mencuri adalah berbuatan melanggar hukum. Konsekuensi dari mencuri adalah menerima hukuman sesuai dengan jenis dan kapasitas pencurian yang dilakukan. Perbuatan membunuh adalah perbuatan yang tidak dilandasi oleh perasaan kasih sayang. Perbuatan tersebut termasuk perbuatan yang tidak menghargai hak azasi manusia. Pembunuhan terhadap manusia merupakan pelanggaran hak azasi manusia (HAM) karena hidup merupakan salah satu hak manusia yang paling azasi. Perbuatan berzinah merupakan perbuatan yang tidak menghargai nilai-nilai atau norma-norma kehidupan. Perbuatan tersebut cenderung mengakibatkan ketidaknyamananan hidup.

Taksonomi Trikaya yang dikembangkan dalam penelitian ini mengambil tiga kegiatan pokok manusia: berpikir, berbicara, dan berbuat sebagai domein penilaian kemampuan atau kompetensi. Namun, aspek-aspek penilaian yang digunakan serta indikatornya dikembangkan berdasarkan kajian teoretis dan empiris lainnya yang diperoleh melalui penelitian yang telah dilakukan. Secara konseptual rumusan Taksonomi Trikaya dapat dipaparkan sebagai berikut.

\begin{tabular}{|c|c|c|}
\hline Domein & Aspek & Indikator Pencapaian \\
\hline \multirow[t]{5}{*}{ Berpikir } & 1. Berpikir faktual & $\begin{array}{l}\text { - } \text { mengidentifikasi fakta-fakta yang digunakan } \\
\text { landasan berpikir } \\
\text { - menjelaskan hubungan fakta-fakta dengan alasan } \\
\text { berpikir }\end{array}$ \\
\hline & 2. Berpikir positif & $\begin{array}{l}\text { - mengidentifikasi kerangka konseptual teoretis } \\
\text { pikiran } \\
\text { - mengidentifikasi kerangka konseptual empiris } \\
\text { pikiran }\end{array}$ \\
\hline & $\begin{array}{l}\text { 3. Berpikir rasional } \\
\text { logis }\end{array}$ & $\begin{array}{l}\text { - mengidentifikasi alasan berpikir } \\
\text { - menjelaskan alasan berpikir sesuai dengan } \\
\text { kaidah ilmiah }\end{array}$ \\
\hline & 4. Berpikir kritis & $\begin{array}{l}\text { - mengidentifikasi hubungan sebab akibat } \\
\text { - meramalkan kejadian yang akan datang } \\
\text { - mengantisipasi kejadian yang akan datang }\end{array}$ \\
\hline & $\begin{array}{l}\text { 5. Berpikir kreatif } \\
\text { inovatif }\end{array}$ & $\begin{array}{l}\text { - } \text { mengidentifikasi kemungkinan } \\
\text { perubahan/perbaikan } \\
\text { - membuat gagasan-gagasan pikiran baru yang } \\
\text { bermanfaat }\end{array}$ \\
\hline \multirow[t]{2}{*}{ Berbicara } & 1. Berbicara santun & $\begin{array}{l}\text { - } \text { mengidentifikasi etika dan tata krama berbicara } \\
\text { - menjelaskan etika dan tata krama berbicara } \\
\text { - berbicara sesuai dengan etika dan tata krama } \\
\text { yang berlaku }\end{array}$ \\
\hline & 2. Berbicara faktual & $\begin{array}{l}\text { - mengidentifikasi fakta-fakta pembicaraan } \\
\text { - menjelaskan fakta-fakta pembicaraan } \\
\text { - berbicara sesuai dengan fakta-fakta yang ada }\end{array}$ \\
\hline
\end{tabular}




\begin{tabular}{|c|c|c|}
\hline & $\begin{array}{l}\text { 3. } \begin{array}{l}\text { Berbicara rasional } \\
\text { logis }\end{array} \\
\text { lat }\end{array}$ & $\begin{array}{l}\text { - mengidentifikasi rasional pembicaraan } \\
\text { - menjelaskan rasional pembicaraan secara ilmiah } \\
\text { - berbicara berdasarkan rasional ilmiah yang } \\
\text { dibanqun }\end{array}$ \\
\hline & $\begin{array}{ll}\text { 4. } & \text { Berbicara } \\
\text { sistematis }\end{array}$ & $\begin{array}{l}\text { - } \text { mengidentifikasi urutan pembicaraan } \\
\text { - menjelaskan aturan urutan pembicaraan } \\
\text { - berbicara sesuai dengan urutan yang } \\
\text { dipersiapkan }\end{array}$ \\
\hline & $\begin{array}{ll}\text { 5. } & \text { Berbicara } \\
\text { komunikatif }\end{array}$ & $\begin{array}{l}\text { - } \text { mengidentifikasi keadaan lawan bicara atau } \\
\text { pendengar } \\
\text { - menjelaskan keadaan lawan bicara atau } \\
\text { pendengar } \\
\text { - berbicara sesuai dengan keadaan lawan bicara } \\
\text { atau pendengar }\end{array}$ \\
\hline \multirow[t]{5}{*}{ Berbuat } & 1. Berbuat sopan & $\begin{array}{l}\text { - nengidentifikasi etika dan tata krama berbuat } \\
\text { - menjelaskan etika dan tata krama berbuat } \\
\text { - berbuat sesuai dengan etika dan tata krama yang } \\
\text { berlaku }\end{array}$ \\
\hline & 2. Berbuat patuh & $\begin{array}{l}\text { - } \text { mengidentifikasi aturan yang melandasai } \\
\text { perbuatan } \\
\text { - } \text { menjelaskan aturan-aturan yang ada } \\
\text { - berbuat mengikuti aturan yang ada }\end{array}$ \\
\hline & 3. Berbuat jujur & $\begin{array}{l}\text { - mengidentifikan kemampuan diri sendiri (fisik dan } \\
\text { - mental) } \\
\text { - menjelaskan hak dan kewajiban } \\
\text { - berbuat sesuai dengan keadaan fisik dan mental } \\
\text { berbuat sesuai dengan hak dan kewajiban }\end{array}$ \\
\hline & 4. Berbuat yakin & $\begin{array}{l}\text { - mengidentifikasi alasan berbuat } \\
\text { - menjelaskan alasan berbuat } \\
\text { - berbuat tanpa keragu-raguan }\end{array}$ \\
\hline & $\begin{array}{l}\text { 5. Berbuat kreatif } \\
\text { inovatif }\end{array}$ & $\begin{array}{l}\text { - mengidentifikan peluang dan tantangan } \\
\text { - menjelaskan peluang dan tantangan yang ada } \\
\text { - berbuat sesuatu yang baru }\end{array}$ \\
\hline
\end{tabular}

\section{Rumusan Domein Taksonomi Trikaya}

Seperti telah dideskripsikan di atas, Taksonomi Trikaya terdiri atas tiga domein, yaitu domein pikiran (manacika), domein perkataan (wacika), dan domein perbuatan (kayika). Ketiga domein tersebut merupakan satu kesatuan yang bersifat hirarkis, dalam arti domein yang satu mempengaruhi domein yang lainnya. Hirarki ketiga domein tersebut dimulai dari domein pikiran, dilanjutkan dengan domein perkataan dan domein perbuatan.

\begin{abstract}
Domein pikiran (manacika)
Domein pikiran adalah domein pertama yang harus dilatih melalui pembelajaran. Hasil belajar dapat dinilai sesuai dengan aktivitas domein pikiran. Dalam hal ini, penilaian hasil belajar harus sesuai dengan pengalaman belajar yang diperoleh peserta didik. Dalam domein pikiran, aktivitas belajar yang harus dinilai meliputi lima aspek penilaian, yaitu: 1) berpikir faktual, 2) berpikir positif, 3) berpikir
\end{abstract}


rasional logis, 4) berpikir kritis, dan 5) berpikir kreatif inovatif.

1) Berpikir faktual

Berpikir faktual adalah berpikir yang dilandasi oleh bukti-bukti atau faktafakta yang ada, bukan berdasarkan atas pendapat atau opini. Dalam hal ini, fakta-fakta atau bukti-bukti yang digunakan sebagai landasan berpikir dapat berupa fakta-fakta nyata, misalnya barang atau benda, dan juga fakta informasi yang diperoleh dengan cara yang dapat dibuktikan kebenarannya secara berulang. Misalnya, fakta suhu air mendidih yang diinformasikan melalui pengukuran dengan termometer. Kemampuan berpikir faktual dapat dilihat dari kemampuan mengidentifikasi fakta-fakta yang digunakan landasan berpikir dan kemampuan menjelaskan hubungan antara fakta-fakta yang ada dengan gagasan pikiran yang dikemukakan.

2) Berpikir positif

Berpikir positif adalah berpikir yang selaras dengan kebenaran yang didasari dengan konstruksi teori. Landasan yang harus digunakan dalam berpikir positif adalah kerangka konseptual teoretis dan empiris yang diperoleh melalui pembelajaran dan pengalaman di sekolah, di keluarga, dan di masyarakat. Kerangka konseptual teoretis adalah kerangka konsep yang diperoleh dari teori-teori yang ada. Sedangkan, kerangka konseptual empiris adalah kerangka konsep yang diperoleh berdasarkan pengalaman. Kemampuan berpikir positif dapat dilihat dari kemampuan untuk mengidentifikasi kerangka konseptual teoretis dan empiris yang digunakan sebagai landasan berpikir.
3) Berpikir rasional logis

Berpikir rasional logis adalah berpikir yang dilandasi oleh rasional yang ilmiah. Artinya, berpikir yang didasarkan atas bukti-bukti ilmiah. Cara berpikir tersebut dapat berupa berpikir terfokus (konvergen) atau berpikir multiarah (divergen). Dalam pembelajaran, kedua cara berpikir tersebut perlu dilatihkan karena masing-masing memiliki keunggulan tersendiri. Berpikir terfokus diperlukan untuk mengenali masalah secara utuh sehingga mudah dipecahkan. Berpikir multiarah diperlukan untuk menyadari adanya perbedaan yang sama-sama memiliki landasan kebenaran. Kemampuan berpikir rasional logis dapat dilihat dari kemampuan untuk mengidentifikasi dan menjelaskan kaidah ilmiah sebagai landasan berpikir.

4) Berpikir kritis

Berpikir kritis adalah berpikir yang didasarkan atas keyakinan terhadap ajaran karma phala. Dalam ajaran karma phala dijelaskan bahwa semua perbuatan ada hasil sebagai akibat dari perbuatan dan semua akibat ada penyebabnya. Dalam hal ini hubungan sebab akibat dijelaskan oleh kerangka waktu yang dikenal dengan masa lalu (atita), masa kini (wartamana), dan masa depan (nagata). Kemampuan berpikir kritis dapat dilihat dari kemampuan untuk melihat hubungan kausalistik dari sebuah masalah, kemampuan untuk memprediksi kejadian yang akan datang, dan kemampuan untuk melakukan antisipasi terhadap hal-hal yang sudah diprediksi.

5) Berbipikir kreatif inovatif

Berpikir kreatif inovatif adalah berpikir yang ke luar dari kebiasan dan

Jurnal Pendidikan Indonesia | 48 
memberikan nilai tambah (pembaharuan). Berpikir kreatif inovatif tidak sekadar berbeda dengan kebiasaan, tetapi berbeda yang menuju pada pembaharuan atau perbaikan, baik dalam bentuk proses maupuan hasil atau capaian. Kemampuan berpikir kreatif inovatif dapat dilihat dari kemampuan mengidentifikasi kemungkinan perubahan/perbaikan dan menjelaskan hal-hal baru yang akan dibuat.

\section{Domein perkataan (wacika)}

Berkata atau berbicara (wacika) merupakan domein kedua dari Taksonomi Trikaya. Kegiatan berbicara dapat dilakukan, baik secara lisan maupun tertulis. Oleh karena itu, pembelajaran dan penilaian domein tersebut dapat dilakukan, baik secara lisan maupun tertulis, sesuai dengan konteks pembicaraan. Berbeda halnya dengan berpikir yang dapat dilakukan secara tidak terbatas, berbicara dibatasi oleh berbagai hal, antara lain norma atau nilai yang berlaku, materi pembicaraan, kemampuan pembicara, dan keadaan lawan bicara atau pendengar. Ada lima aspek yang dapat dinilai dalam domein berbicara, yaitu: 1) berbicara santun, 2) berbicara faktual, 3) berbicara rasional logis, 4) berbicara sistematis, dan 5) berbicara komunikatif.

1) Berbicara santun

Berbicara santun adalah berbicara yang sesuai dengan etika tata cara bertutur kata yang memperhatikan penggunaan pilihan kata, isi pembicaraan, arah pembicaraan dan lawan bicara. Berbicara santun juga terkait dengan jenis dan ragam bahasa yang digunakan. Kemampuan berbicara santun dapat dilihat dari kemampuan mengidentifikasi dan menjelaskan etika dan tata krama berbicara serta kemampuan berbicara sesuai dengan etika dan tata krama yang berlaku.

2) Berbicara faktual

Berbicara faktual adalah berbicara yang dilandasi oleh bukti-bukti atau faktafakta yang ada, bukan berdasarkan atas pendapat atau opini yang berkembang. Dalam hal ini, fakta-fakta atau buktibukti yang digunakan sebagai landasan berbicara dapat berupa fakta-fakta nyata, misalnya barang atau benda, dan juga fakta-fakta informasi yang diperoleh dengan cara yang dapat dibuktikan kebenarannya secara berulang. Misalnya, fakta suhu air mendidih yang diinformasikan melalui pengukuran dengan termometer. Kemampuan berbicara faktual dapat dilihat dari kemampuan mengidentifikasi dan menjelaskan fakta-fakta pembicaraan, serta berbicara sesuai dengan faktafakta yang ada.

3) Berbicara rasional logis

Berbicara rasional logis adalah berbicara yang disertai dengan alasan yang mempunyai nilai kebenaran ilmiah. Pembicaraan yang rasional logis adalah pembicaraan yang sesuai dengan kerangka kebenaran yang dipahami secara umum. Pembicaraan yang rasional logis mudah dipahami oleh pendengar dan tidak menyesatkan. Kemampuan berbicara rasional logis dapat dilihat dari kemampuan mengidentifikasi dan menjelaskan rasional materi pembicaraan, serta berbicara sesuai dengan rasional ilmiah.

4) Berbicara sistematis

Berbicara sistematis adalah berbicara dengan struktur yang jelas dan terikat dengan konteks pembicaraan. Struktur

Jurnal Pendidikan Indonesia | 49 
pembicaraan terkait dengan masalah atau objek yang dibicarakan dan juga pendengar/pembaca.

Berbicara sistematis adalah berbicara yang tidak melompat-lompat atau mempunyai kronologis yang jelas. Kemampuan berbicara sistematis dapat dilihat dari kemampuan mengidentifikasi dan menjelaskan urutan-urutan pembicaraan, serta berbicara sesuai dengan urutan yang dipersiapkan.

5) Berbicara komunikatif

Berbicara komunikatif adalah berbicara yang mudah diterima oleh pendengar atau pembaca. Dalam hal ini, pembicara harus dilatih untuk berbicara sesuai dengan keadaan pendengar. Di samping itu, pembicaraan hendaknya disampaikan secara simpatik dan empatik sehingga membuat pendengar nyaman dan tertarik untuk mendengarkan. Kemampuan berbicara komunikatif dapat dilihat dari kemampuan mengidentifikasi dan menjelaskan keadaan lawan bicara atau pendengar, serta berbicara sesuai dengan keadaan lawan bicara atau pendengar.

\section{Domein perbuatan (kayika)}

Perbuatan merupakan domein ketiga dari Taksonomi Trikaya. Perbuatan merupakan wujud nyata dari pikiran dan perkataan yang secara langsung dapat memberikan dampak pada perubahan lingkungan. Dapat dinyatakan bahwa dari ketiga domein Taksonomi Trikaya, domein perbuatan adalah domein terpenting karena berdampak langsung kepada yang melakukan perbuatan dan yang dikenai perbuatan tersebut. Namun demikian, kegiatan berbuat mempunyai keterbatasan yang paling besar di antara ketiganya.
Misalnya, dalam praktik kehidupan demokrasi, orang-orang memiliki kebebasan berpikir dan berbicara, tetapi tidak memiliki kebebasan berbuat. Perbuatan harus dilakukan secara ketat dengan mempertimbangkan keadaan tempat (desa), waktu (kala), dan kondisi (awastha) (Maswinara, 1996). Ada lima aspek yang dapat digunakan untuk menilai pebuatan, yaitu: 1) berbuat sopan, 2) berbuat patuh, 3) berbuat jujur, 4) berbuat yakin, dan 5) berbuat kreatif inovatif.

1) Berbuat sopan

Berbuat sopan adalah berbuat sesuai dengan etika tata krama berbuat yang diterima sesuai dengan keadaan tempat berbuat. Keadaan yang dimaksud terdiri atas keadaan tempat berbuat, keadaan waktu berbuat, dan keadaan tatanan sosial atau kebiasaan yang berlaku di tempat berbuat. Kemampuan berbuat sopan dapat dilihat dari kemampuan mengidentifikasi etika dan tata krama berbuat, dan kemampuan berbuat sesuai dengan etika dan tata krama yang ada.

2) Berbuat patuh

Berbuat patuh adalah berbuat yang sesuai dengan peraturan. Dalam hal ini, perbuatan yang dilakukan harus selalu berbijak pada peraturan yang berlaku di tempat berbuat. Misalnya, perbuatan di sekolah harus sesuai dengan peraturan sekolah; perbuatan di desa harus sesuai dengan peraturan desa; perbuatan di tingkat negara harus sesuai dengan peraturan negara. Dalam konsep kearifan lokal masyarakat Bali, perilaku tersebut dinyatakan dengan ungkapan, "sesana manut linggih, linggih manut sesana" (kewajiban dilakukan sesuai dengan tempat atau kedudukan, atau tempat atau kedudukan dijalankan Jurnal Pendidikan Indonesia | 50 
sesuai dengan kewajiban). Perbuatan yang dilakukan sesuai dengan aturan akan menghasilkan kedamaian dan keharmonisan, baik untuk diri sendiri maupun orang lain. Kemampuan berbuat patuh dapat dilihat dari kemampuan mengidentifikasi dan mejelaskan peraturan yang ada, serta berbuat sesuai dengan peraturan tersebut.

3) Berbuat jujur

Berbuat jujur adalah berbuat sesuai dengan kemampuan yang didasarkan atas hak dan kewajiban. Kemampuan yang dimaksud di sini meliputi, baik kemampuan fisik maupun mental. Dalam berbuat, seseorang hendaknya bercermin pada kemampuan dirinya serta hak dan kewajibannya sesuai dengan tugas yang diembannya. Sesederhana apapun perbuatan seseorang yang dilakukan sesuai dengan swadharmanya masih lebih baik daripada orang tersebut melaksanakan swadharma orang lain. Kemampuan berbuat jujur dapat dilihat dari kemampuan mengidentifikasi dan menjelaskan keadaan fisik dan mental, serta hak dan kewajiban, dan berbuat sesuai dengan hak dan kewajiban.

4) Berbuat yakin

Berbuat yakin adalah berbuat yang dilakukan dengan penuh percaya diri bahwa perbuatan yang dilakukan adalah benar. Dalam hal ini, kebenaran perbuatan dilihat dari kesesuaian dengan etika dan tata krama berbuat, sesuai dengan peraturan yang ada, dan sesuai dengan keadaan fisik dan mental serta hak dan kewajiban (jujur). Kemampuan berbuat yakin dapat dilihat dari kemampuan mengidentifikasi dan menjelaskan alasan berbuat, serta berbuat tanpa keragu-raguan.

5) Berbuat kreatif inovatif

Berbuat kreatif inovatif adalah berbuat yang berbeda dengan kebiasaan yang ada. Namun, perbuatan tersebut berorientasi pada perbaikan atau mengandung nilai-nilai pembaruan. Oleh karena itu, perbuatan kreatif inovatif tetap harus dilakukan secara sopan, patuh, jujur, dan penuh percara diri (yakin). Keberanian untuk berbuat kreatif inovatif akan menjadi landasan perkembangan ilmu pengetahuan dan teknologi. Kemampuan berbuat kreatif inovatif dapat dilihat dari kemampuan mengidentifikasi peluang dan tantangan yang ada, dan kemampuan membuat sesuatu yang baru.

\section{PENUTUP}

Taksonomi Trikaya merupakan taksonomi pembelajaran dan penilaian hasil belajar berbasis kompetensi yang dirumuskan berdasarakan nilai-nilai kearifan lokal masyarakat Bali. Nilai-nilai kearifan lokal masyarakat Bali yang dijadikan dasar perumusan adalah nilai-nilai ajaran kebajikan berbuat yang diklasifikasikan dalam tiga kategori perbuatan, yaitu: berpikir (manacika), berbicara (wacika), dan berbuat/berperilaku (kayika). Tiga jenis perbuatan tersebut merupakan susunan hirarkis dari tiga domein pembelajaran dan penilaian hasil berlajar yang dikembangkan. Penilaian tiap-tiap domein didasarkan atas aspek-aspek penilaian yang juga disusun secara hirarkis. Tiap-tiap domein penilaian terdiri atas lima aspek penilaian dan sejumlah indikator penilaian yang dapat dijadikan sebagai acuan dalam merumuskan tujuan pembelajaran dan penilaian hasil belajar berbasis kompetensi.

Jurnal Pendidikan Indonesia | 51 
Dalam hal ini, tujuan pembelajaran dapat dirumuskan sesuai dengan aspek domein yang hendak dikembangkan dalam pembelajaran. Misalnya, pengembangkan kemampuan berpikir kritis dapat dilakukan dengan merumuskan tujuan pembelajaran dan asesmen hasil belajar yang diarahkan pada kemampuan berpikir kausalistik, prediktif, dan antisipatif.

\section{DAFTAR PUSTAKA}

Borg, W. R. \& Gall, M. D. 1989. Educational Research: An Introductionl. New York: Longman.

Dimyati \& Mudjiono. 2002. Belajar dan Pembelajaran. Jakarta: Rineka Cipta.

Maswinara, I Wayan. 1996. Konsep Panca Sradha. Surabaya: Paramita.

Mulyasa, E. 2007. Kurikulum Tingkat Satuan Pendidikan. Bandung: Remaja Rosda Karya.

Parisada Hindu Dharma Pusat. 1979. Sarasamuschaya. Alih Bahasa oleh Tjokorda Rai Sudharta,M.A.

Punyatmadja, I. B. Oka. 1976. Panca Cradha. Denpasar: Parisada Hindu Dharma.

Sudharta, T. R. \& Atmaja, I. B. Punia. 2001. Upadesa tentang Ajaran-ajaran Agama Hindu. Surabaya: Paramita.

Subagia, I Wayan. 2004. Implementasi Kurikulum 2004: Tantangan Guru dan Merencanakan dan Melaksanakan Pembelajaran di Sekolah. Jurnal IKA Vol. 2. No.1. Hal 1-3. IKIP Negeri Singaraja.

Subagia, I Wayan. 2006. Evaluasi Pelaksanaan Uji Coba Kurikulum 2004 di Sekolah Menengah Atas. Jurnal Pendidikan dan Pengajaran IKIP Negeri Singaraja, Vol. 39. No. 2. TH. XXXIX. April.

Subagia, I Wayan \& Wiratma, I G. L. 2009. Penilaian Kemampuan Individu Melaksanakan Tupoksi dalam Organisasi Masyarakat Tradisional Bali Ditinjau dari Konsep "Tri Kaya
Parisudha." Jurnal Pendidikan dan Pengajaran UNDIKSHA Jilid 42. No.2. Hal. 160 - 169.

Subagia, I Wayan \& Wiratma, I G. L. 2010. Penilaian kompetensi kepala sekolah dan guru Dalam bekerja di sekolah Jurnal Pendidikan dan Pengajaran UNDIKSHA (dalam proses). 


\title{
PENGEMBANGAN PERANGKAT VISUALISASI KOMPUTER SISTEM AKUNTANSI BERBASIS ICT DENGAN MODEL PEMBELAJARAN BERPENDEKATAN CTL
}

\author{
Lucy Sri Musmini ${ }^{1}$, Gede Adi Yuniarta ${ }^{2}$ \\ 1, 2Jurusan Akuntansi Program Diploma III, Fakultas IImu Sosial \\ Universitas Pendidikan Ganesha \\ Singaraja, Indonesia \\ e-mail:musmini@yahoo.co.id; gdadi_ak@yahoo.co.id
}

\begin{abstract}
Abstrak
Penelitian ini dilatarbelakangi oleh pesatnya perkembangan ilmu pengetahuan dan teknologi yang terjadi dalam ilmu akuntansi. Tuntutan era global akan kemampauan professional mengharapkan tenaga kerja bidang akuntansi harus bisa menguasai kombinasi perkembangan ilmu akuntansi dan teknologi dalam melaksanakan tugas mereka sehari-hari. Apalagi perkembangan teknologi komputer berbasis Information and Communication Technology (ICT) yang sudah tidak membedakan jarak dalam penyusunan laporan keuangan akuntansi. Tujuan jangka panjang penelitian ini adalah terwujudnya Perangkat Visualisasi Komputer Sistem Akuntansi Berbasis Information and Communication Technology (ICT) Dengan Model Pembelajaran Berpendekatan Contextual Teaching And Learning yang valid, praktis, relevan dan mengikuti pesatnya perkembangan ilmu pengetahuan dan teknologi. Penelitian ini menggunakan model pengembangan perangkat pembelajaran Instructional Development Model (ID Model). Hasil penelitian menunjukkan bahwa: (1) Perangkat visualisasi sistem akuntansi yang menjadi produk penelitian sampai dengan tahun kedua ini menggambarkan bagaimana sistem akuntansi suatu perusahaan dengan berbasis kasus-kasus akuntansi yang diprioritaskan dalam bentuk: formulir, Jurnal, buku besar, buku besar pembantu dan laporan keuangan. Perangkat visualisasi sistem akuntansi ini baru berupa media visualisasi yang belum di link dengan perkembangan ICT. (2) Terkait pada kepuasan pengguna dalam perkuliahan secara general menunjukkan bahwa sebanyak $31,4 \%$ peserta kuliah merasa sangat puas dengan produk penelitian, sebagian besar peserta kuliah atau $61,6 \%$ merasa puas dengan pemanfaat perangkat visualisasi namun masih ada peserta sebanyak $7,1 \%$ merasa kurang puas dalam pemanfaatan perangkat visualisasi dalam rangka pembelajaran mata kuliah Sistem Akuntansi. Hal ini menunjukkan produk penelitian masih perlu untuk disempurnakan lagi baik dari segi substansi maupun dalam hal tampilan dan kepraktisan operasional.
\end{abstract}

Kata Kunci: Visualisasi komputer, sistem akuntansi, ICT dan Contextual Teaching And Learning 


\begin{abstract}
This research was motivated by the rapid development of science and technology that occurred in the science of accounting. Demands of the global era will expect professional workforce in accounting should be able to master the combination of accounting and technology development of science in their work everyday. Moreover, the development of computer technology-based Information and Communication Technology (ICT) which is no respecter of distance in the preparation of financial statements of accounting. The long term goal of this study was the realization of Visualization Tool Computer-Based Accounting System Information and Communication Technology (ICT) Learning Models With Contextual Teaching And Learning a valid, practical, relevant and to follow the rapid development of science and technology. This study uses a model of development learning Instructional Development Model (ID Model). The results showed that: (1) The visualization of the accounting system into the product until the second year of study illustrates how the accounting systems of an enterprise-based accounting cases are prioritized in the form: form, journal, general ledger, subsidiary ledgers and reports finance. Visualization device is a new accounting system in the form of visualization media that have not been in the link with the development of ICT. (2) Related to the satisfaction of users in a general course showed that study participants as much as $31.4 \%$ were very satisfied with the product of research, most participants go to college or $61.6 \%$ of users were satisfied with the device visualization but there is still a participant as much as $7.1 \%$ felt less satisfied in the use of visualization tools in order to study subjects Accounting System. This shows the product of research still needs to be refined again in terms of both substance and in terms of appearance and operational practicality.
\end{abstract}

Keywords: Visualization of computer systems, accounting, ICT and Contextual Teaching And Learning

\section{PENDAHULUAN}

Tenaga profesional di bidang akuntansi yang merupakan lulusan dari Jurusan Diploma III memerlukan kemampuan profesional termasuk dalam pemanfaatan teknologi untuk dapat tetap eksis di dalam mengahadapi tuntutan era global. Berbagai perkembangan teknologi sudah selayaknya dapat dimanfaatkan guna meningkatkan kompetensi di bidang akuntansi. Salah satu mata kuliah yang mengkaji kombinasi bidang ilmu akuntansi dan perkembangan teknologi adalah mata kuliah Sistem Akuntansi (Buku Pedoman Studi.2006). Penguasaan mahasiswa dalam mata kuliah ini ditujukan supaya mahasiswa dapat memahami sistem akuntansi yang diterapkan di berbagai bidang usaha termasuk perkembangan ilmu akuntansi yang dikaitkan dengan perkembangan teknologi guna memecahkan berbagai kasus akuntansi pada berbagai jenis bidang usaha yang ada baik untuk perusahaan jasa, dagang bahkan untuk perusahaan manufaktur (Profil Jurusan Diploma III Akuntansi. 2007).

Upaya yang mungkin dilaksanakan adalah dengan pola pembelajaran yang tepat dan memanfaatkan perkembangan teknologi salah satunya dengan pemanfaatan hasil pengembangan program komputer akuntansi terpadu. Program komputer akuntansi terpadu merupakan sebuah program yang dibuat untuk olah data akuntansi secara terpadu program komputer ini membantu mengolah data keuangan untuk diolah menjadi berbagai informasi keuangan. Pemanfaatan program komputer akuntansi terpadu disini adalah dalam 
bentuk visualisasi berbagai sistem akuntansi melalui program komputer sehingga peserta didik/ mahasiswa dapat lebih memahami konteks dari materi perkuliahan. Perkuliahan dikondisikan lebih menarik dengan visualisasi sistem akuntansi yang mengetengahkan materi perkuliahan secara kontektual (Contextual Teaching And Learning). Dengan pola pembelajaran Contextual Teaching And Learning dengan bantuan visualisasi komputer maka akan membantu dosen mengkaitkan materi (content) yang diajarkan dengan situasi dunia nyata dan mendorong mahasiswa membuat hubungan-hubungan antara pengetahuan yang dimilikinya dengan penerapannya dalam kehidupan mereka sehari-hari. Pengetahuan dan keterampilan mahasiswa diperoleh dari usaha siswa mengkonstruksi sendiri pengetahuan dan keterampilan baru ketika ia belajar. Landasan filosofi pembelajaran contextual adalah konstruktivisme, yaitu filosofi belajar yang menekankan bahwa belajar tidak hanya sekedar menghapal. Siswa harus mengkonstruksikan pengetahuan di benak mereka sendiri. Bahwa pengetahuan tidak dapat dipisah-pisahkan menjadi fakta-fakta atau proposisi yang terpisah, tetapi mencerminkan keterampilan yang dapat diterapkan. Dengan kombinasi pola pembelajaran Contextual Teaching And Learning dan visualisasi Sistem akuntansi dengan program komputer akuntansi terpadu maka proses pembelajaran diharapkan dapat menjadi lebih sistematis sehingga kualitas pembelajar dapat ditingkatkan. Tujuan dari penelitian ini adalah terwujudnya Perangkat Visualisasi Komputer Sistem Akuntansi Berbasis Information and Communication Technology (ICT) Dengan Model Pembelajaran Berpendekatan Contextual Teaching And
Learning yang valid, praktis, relevan dan mengikuti pesatnya perkembangan ilmu pengetahuan dan teknologi.

\section{METODE}

Dalam penelitian ini digunakan model pengembangan perangkat pembelajaran Instructional Development Model (ID Model) yang sering disebut model UNESCO(Arnyana, 2006). Tahap kegiatan dari model ini dibagi menjadi: Determinasi Masalah (Problem Determination), Desain (Design) dan Pengembangan (Development). Penelitian ini dilakukan di Universitas Pendidikan Ganesha Singaraja, tepatnya di Jurusan Akuntansi. Penelitian dilakukan selama tiga tahun yaitu mulai tahun 2010 sampai dengan tahun 2012.

\section{HASIL DAN PEMBAHASAN}

Kegiatan penelitian di tahun pertama difokuskan pada tahapan determinasi Masalah (Problem Determination) dan desain (design).

Dalam tahap ini kegiatan dikelompokkan dalam beberapa langkah yang dapat didiskripsikan sebagai berikut: (1) Identifikasi masalah: dalam tahap ini dilakukan identifikasi masalah-masalah yang timbul dalam pelaksanaan perkuliahan Sistem Akuntansi. Identifikasi masalah ini dikumpulkan berdasarkan pengalaman pengajaran mata kuliah yang sama pada waktu sebelumnya (pengalaman mengajar sebelumnya) selain itu identifikasi masalah ini juga diperoleh dari mahasiswa yang sudah menempuh mata kuliah bersangkutan. Dalam tahap ini masalah dalam perkuliahan Sistem Akuntansi dapat dikelompokkan dalam dua masalah utama yaitu: (1) Permasalahan teknis perkuliahan yang menyangkut penguasaan akan skill operasional komputer peserta didik yang

Jurnal Pendidikan Indonesia | 55 
tidak merata dan waktu perkuliahan yang dianggap kurang cukup untuk dapat menguasai materi perkuliahan yang padat dengan target penyelesaian kasus akuntansi baik untuk perusahaan jasa, dagang maupun manufaktur, (2) Permasalahan substansi perkuliahan yang meliputi dalam perkuliahan sistem akuntansi selayaknya mahasiswa sudah memahami semua substansi perkuliahan yang mendukung keilmuan akuntansi, seperti, akuntansi keuangan, akuntansi biaya, perpajakan, perbankan dan yang lainnya. Namun realitanya belum semua mata kuliah tersebut sudah ditempuh mahasiswa.

Dalam tahap identifikasi masalah permasalahan yang ternyata muncul dari perkuliahan yang terjadi adalah bahwa permasalahan dikelompokkan dalam dua kategori yaitu: permasalahan teknis pelaksanaan perkuliahan dan permasalahan substansi perkuliahan. Dalam permasalahan teknis perkuliahan ternyata penguasaan akan skill operasional komputer peserta didik yang tidak merata. Perlu adanya strategi pembelajaran yang mampu mengakomodasi sehingga mahasiswa lebih terbiasa dengan penguasaan perkembangan teknologi termasuk operasionalisasi perkembangan Information and Commonication Technology terutama dalam system jaringan (LAN). Sedangkan mengenai waktu perkuliahan yang dianggap kurang cukup memang mahasiswa memandang bahwa waktu perkuliahan yang disediakan tidak cukup untuk memahami materi yang harus mereka terima, dalam hal ini ada beberapa point yang bisa dicermati bahwa pertama mahasiswa masih memandang bahwa perkuliahan hanya berlangsung didalam kelas saja tanpa menyadari makna sesungguhnya dari sistem SKS (sistem kredit semester), hal kedua yang harus dicermati bahwa alokasi waktu yang tersedia memang harus dimanfaatkan semaksimal mungkin sehingga diperlukan sistematika (skenario) perkuliahan yang tepat disertai perangkat pembelajaran yang tepat pula. Dari hasil identifikasi permasalahan ini nampak jelas bahwa dalam teknis perkuliahan menunjukkan kurang sistematis.

Kasus akuntansi yang disiapkan diharapkan lebih mendekati kondisi riil di dunia usaha, lebih fleksible mengingat kondisi dunia usaha yang fleksible serta keterkaitan dengan bidang lain seperti asuransi, sistem perbankan, perpajakan dan lainnya. Kasus akuntansi yang dibahas juga diharapkan tidak kaku cenderung mendekati contoh - contoh yang ada dibuku saja namun sudah mengarah pada kondisi yang dapat meningkatkan kemampuan analisa dan kemampuan prediksi mahasiswa. Seiring dengan hal tersebut kertas kerja akuntansi yang disiapkan diharapkan juga disesuaikan secara khusus dengan kasus akuntansi yang dihadapi, kertas kerja selayaknya sistematis dan memiliki format terkini selayaknya yang berlaku di dunia kerja.

Penyiapan berbagai materi sistem akuntansi dengan fokus berbasis CTL. Materi difokuskan pada kasus-kasus akuntansi yang mencerminkan kegiatan riil di dunia kerja. Kasus akuntansi ini diharapkan akan dapat memancing meningkatnya kemampuan analisis dalam penyelesaian terhadap masalah sehingga akan menghasilkan perolehan pengetahuan dan keterampilan pemecahan masalah. Kasus yang disusun juga dikaitkan dengan disiplin lain seperti perbankan, pajak, asuransi, penggajian dan lainnya. Setelah itu dilakukan analisis hasil dengan melibatkan rekan seprofesi serta rekan ahli. 
Peran rekan seprofesi sesama Dosen Jurusan Akuntansi disini adalah memberikan masukan atas substansi perkuliahan mulai dari bagaimana penyusunan kasus- kasus akuntansi sehingga bisa mendekati kondisi rill di lapangan, bagaimana kasus akuntansi yang disusun bisa lebih komprehensif saling terkait dengan bidang lainnya seperti: asuransi, perbankan, bisnis dan perpajakan.

Setelah materi perkuliahan siap baru dimulai merancang perangkat visaualisasi sistem akuntansi. Perangkat visualisasi ini desain dengan menggunakan program Visual Basic. Secara sederhana perangkat visualisasi ini menggambarkan bagaimana sistem akuntansi suatu perusahaan dengan berbasis kasus-kasus akuntansi. Sistem akuntansi merupakan organisasi formulir, catatan, dan laporan yang di koordinasikan sedemikian rupa untuk menyediakan informasi keuangan yang dibutuhkan oleh manajemen guna memudahkan pengelolaan perusahaan. Dalam perangkat visualisasi ini elemenelemen pembentuk sistem akuntansi diprioritaskan dalam hal penyajiannya diantara elemen-elemen tersebut diataranya: (1) Formulir, merupakan dokumen yang digunakan untuk merekam terjadinya transaksi. Jurnal merupakan catatan akuntansi pertama yang digunakan untuk mencatat, mengklasifikasikan, dan meringkas data keuangan dan data lainnya. Sumber informasi pencatatan dalam jurnal ini adalah formulir. Dalam jurnal ini data keuangan untuk pertama kalinya diklasifikasikan menurut penggolongan yang sesuai dengan informasi yang akan disajikan dalam laporan keuangan. Dalam jurnal ini pula terdapat kegiatan peringkasan data, yang hasil peringkasannya (berupa jumlah rupiah transaksi tertentu) kemudian di-posting ke rekening yang bersangkutan dalam buku besar. Contoh jurnal adalah jurnal penerimaan kas, jurnal pembelian, jurnal penjualan, dan jurnal umum, (2) Buku besar (general ledger) terdiri dari rekeningrekening yang digunakan untuk meringkas data keuangan yang telah dicatat sebelumnya dalam jurnal. (3) Buku Pembantu, Jika data keuangan yang digolongkan dalam buku besar diperlukan rinciannya lebih lanjut, dapat dibentuk buku besar pembantu (subsidiary ledger), (4) Laporan keuangan, hasil akhir proses akuntansi adalah laporan keuangan yang dapat berupa neraca, laporan rugi laba, laporan arus kas, laporan harga pokok produksi, laporan biaya pemasaran, laporan harga pokok penjualan, daftar umur piutang, daftar utang yang akan dibayar, daftar saldo persediaan yang lambat penjualannya. Laporan berisi informasi yang merupakan keluaran sistem akuntansi.

Penelitian tahun kedua dilakukan pengembangan/penyempurnaan perangkat pembelajaran yang telah dilakukan pada tahap Desain. Kegiatan pengembangan yang dilakukan berupa mengembangkan Perangkat Visualisasi Komputer Sistem Akuntansi yang merupakan pengembangan program Komputer Akuntansi standar yang masih harus disempurnakan/dikembangkan sesuai dengan Standar Akuntansi Keuangan Indonesia dilengkapi dengan sistem operasional dalam penyelesaian kasuskasus akuntansi riil di dunia kerja. Pengembangan juga disertai dengan penyusunan bahan ajar dalam bentuk draf bahan ajar Sistem Akuntansi yang berisikan materi sistem akuntansi disertai manual dari perangkat Visualisasi Komputer Sistem Akuntansi dengan kasus-kasus akuntansi riil di dunia kerja beserta proses penyelesaian kasus (dapat dilihat pada lampiran produk penelitian ini). 
Setelah penyempurnaan perangkat selesai dilakukan maka tahapan terakhir yang dilakukan dalam penelitan di tahun kedua ini adalah uji coba pemanfaatan perangkat visualisasi dalam kegiatan pembelajaran yang sesungguhnya di kelas. Pada uji coba ini dilakukan simulasi penggunaan perangkat pada pembelajaran sesungguhnya dengan jumlah peserta sebanyak 106 orang. Pemanfaatan perangkat visualisasi digunakan dalam proses pembelajaran digunakan sebagai sarana pendukung dalam penguasaan substansi perkuliahan. Kebermanfaatan sarana visualisasi diuji dengan penyebaran kuisioner ke peserta kuliah. Kuisioner berisikan tentang kepuasan peserta terhadap pemanfaatan sarana visualisasi dalam proses pembelajaran yang meliputi: tampilan umum dan media yang digunakan, format sistematika, informasi yang terkandung (substansi dan relevansi keilmuan), serta kepraktisan dalam penggunaan. Hasil dari uji coba ini dapat dilihat pada tabel berikut ini:

Tabel 1

Kepuasan Peserta Dalam Rangka Pemanfaatan

Perangkat Visualisasi Sistem Akuntansi

\begin{tabular}{|c|c|c|c|c|c|c|}
\hline No. & Keterangan & $\begin{array}{l}\text { Sangat } \\
\text { puas }\end{array}$ & puas & $\begin{array}{l}\text { Kurang } \\
\text { Puas }\end{array}$ & $\begin{array}{l}\text { Tidak } \\
\text { puas }\end{array}$ & $\begin{array}{c}\text { Sangat } \\
\text { tidak } \\
\text { puas }\end{array}$ \\
\hline 1 & $\begin{array}{l}\text { Tampilan umum dan media yang } \\
\text { digunakan }\end{array}$ & $29,2 \%$ & $55,7 \%$ & $15,1 \%$ & - & - \\
\hline 2 & sistematika perangkat & $30,2 \%$ & $63,2 \%$ & $6,6 \%$ & - & - \\
\hline 3 & $\begin{array}{l}\text { Informasi yang terkandung (substansi } \\
\text { dan relevansi keilmuan) }\end{array}$ & $21,7 \%$ & $73,6 \%$ & $4,7 \%$ & - & - \\
\hline 4 & Kepraktisan dalam penggunaan & $44,3 \%$ & $53,8 \%$ & $1,9 \%$ & - & - \\
\hline & Rata -rata & $31,4 \%$ & $61,6 \%$ & $7,1 \%$ & & \\
\hline
\end{tabular}

Berdasarkan dari tabel 3.1 maka dapat diuraikan bahwa dari tampilan umum dan media yang digunakan menyatakan bahwa sebanyak $29,2 \%$ sangat puas dengan pemanfaatan perangkat visualisasi dan sebanyak $55,7 \%$ puas namun ada jumlah yang cukup besar yaitu $15,1 \%$ menyatakan kurang puas dengan tampilan umum dan media yang digunakan. Sedangkan untuk format sitematika perangkat visualisasi sebagian besar peserta yaitu 30,2\% puas, sebanyak $63,2 \%$ sangat puas dan masih ada sisanya sebanyak $6,6 \%$ merasa tidak puas dengan format sistematika perangkat visualisasi. Sedangkan untuk informasi yang terkandung (substansi dan relevansi keilmuan) sebanyak $21,7 \%$ sangat puas dengan inforrmasi yang terkandung dalam perangkat visualisasi, sebanyak $73,6 \%$ sangat puas dan sisanya $4,7 \%$ menyatakan kurang puas. Sedangkan untuk kepraktisan dalam penggunaan sebanyak $44,3 \%$ yang merasa sangat puas dan sebanyak $53,8 \%$ menyatakan sangat puas. Dari uraian tabel 3.1 ini maka secara general dapat disimpulkan bahwa sebagian peserta kuliah 
atau $61,6 \%$ merasa puas dengan pemanfaat perangkat visualisasi bahkan sebanyak 31,4 merasa sangat puas, namun masih ada peserta sebanyak $7,1 \%$ merasa kurang puas dalam pemanfaatan perangkat visualisasi dalam rangka pembelajaran mata kuliah Sistem Akuntansi.

Sedangkan untuk hasil dari evaluasi belajar implementasi dibatasi pada materi system akuntansi untuk perusahaan jasa dan dagang.uji coba hanya dilakukan selama setengah semester mengingat perkuliahan masih berlangsung sampai dengan bulan januari 2012. Evaluasi dibagi menjadi tiga bagian yaitu berdasarkan aktivitas, tugas-tugas dan ujian tengah semester.

Dalam pelaksanaan perkuliahan aktivitas mahasiswa diamati terutama dalam hal penguasaan akan skill komputer dan keaktifan dalam sesion diskusi serta kemampuan mempresentasikan hasil belajar termasuk dalam hal kehadiran mahasiswa. Penilaian untuk aktivitas mahasiswa ini dikelompokkan ke dalam dua sesion yaitu untuk sesion sistem akuntansi untuk perusahaan jasa, dan sistem akuntansi untuk perusahaan dagang. Hasil belajar tersebut dapat di lihat dalam tebel berikut ini:

Tabel 2

Hasil Belajar Dari Aktivitas Mahasiswa Di Kelas

\begin{tabular}{llllllll}
\hline & & \multicolumn{5}{c}{ Persentase jumlah mahasiswa dengan nilai } \\
\cline { 3 - 7 } No. & \multicolumn{1}{c}{ Keterangan } & $\mathbf{0 - 3 9}$ & $\mathbf{4 0 - 5 4}$ & $\mathbf{5 5 - 6 9}$ & $\mathbf{7 0 - 8 4}$ & $\mathbf{8 5 - 1 0 0}$ & Total \\
\hline 1 & $\begin{array}{l}\text { Sistem akuntansi untuk } \\
\text { perusahaan jasa }\end{array}$ & $0 \%$ & $0 \%$ & $1,9 \%$ & $63,2 \%$ & $34,9 \%$ & $100 \%$ \\
\hline 2 & $\begin{array}{l}\text { Sistem akuntansi untuk } \\
\text { perusahaan dagang }\end{array}$ & $0 \%$ & $0 \%$ & $3,8 \%$ & $52,9 \%$ & $43,3 \%$ & $100 \%$ \\
\hline
\end{tabular}

Sedangkan penilaian terhadap mahasiswa yang dilakukan terhadap tugastugas yang mereka kerjakan (dalam bentuk portofolio). Tagihan dalam bentuk portofolio ini juga dikatagorikan dalam dua kelompok yaitu untuk komputer akuntansi untuk perusahaan jasa, dan dagang. Di dalam masing-masing kelompok tersebut tagihan juga dikategorikan dalam tugas individu, kelompok dan perancangan sistem program akuntansi secara mandiri. Hasil belajar tersebut dapat dilihat dalam tabel berikut ini:

Tabel 3

Hasil Belajar Dari Tugas-tugas yang Dikumpulkan Mahasiswa

\begin{tabular}{llllllll}
\hline & & \multicolumn{6}{c}{ Persentase jumlah mahasiswa dengan nilai } \\
\cline { 3 - 7 } No. & \multicolumn{1}{c}{ Keterangan } & $\mathbf{0 - 3 9}$ & $\mathbf{4 0 - 5 4}$ & $\mathbf{5 5 - 6 9}$ & $\mathbf{7 0 - 8 4}$ & $\mathbf{8 5 - 1 0 0}$ & Total \\
\hline 1 & $\begin{array}{l}\text { Sistem akuntansi untuk } \\
\text { perusahaan jasa }\end{array}$ & $0 \%$ & $0 \%$ & $0 \%$ & $54,7 \%$ & $45,3 \%$ & $100 \%$ \\
\hline 2 & $\begin{array}{l}\text { Sistem akuntansi untuk } \\
\text { perusahaan dagang }\end{array}$ & $0 \%$ & $0 \%$ & $1,9 \%$ & $58,5 \%$ & $39,6 \%$ & $100 \%$ \\
\hline
\end{tabular}


Penilaian akhir terhadap hasil belajar mahasiswa baru sebatas pada pelaksanaan Ujian Tengah Semester dengan hasil dapat dilihat dalam tabel berikut ini:

Tabel 4

Hasil Evaluasi Mahasiswa

\begin{tabular}{|l|l|l|l|l|l|l|l|}
\hline \multirow{2}{*}{ No. } & Keterangan & \multicolumn{4}{c|}{ Persentase jumlah mahasiswa dengan nilai } \\
\cline { 3 - 7 } & & $\mathbf{0 - 3 9}$ & $\mathbf{4 0 - 5 4}$ & $\mathbf{5 5 - 6 9}$ & $\mathbf{7 0 - 8 4}$ & $\mathbf{8 5 - 1 0 0}$ & \multicolumn{1}{|c|}{ Total } \\
\hline 1 & Ujian Tengah Semester & $0 \%$ & $0 \%$ & $0,9 \%$ & $54,7 \%$ & $44,3 \%$ & $100 \%$ \\
\hline 2 & Ujian Akhir Semester & $0 \%$ & $0 \%$ & $0 \%$ & $0 \%$ & $0 \%$ & $0 \%$ \\
\hline
\end{tabular}

Pesatnya perkembangan ilmu pengetahuan dan teknologi telah menuntut pada kemampuan professional dosen dalam mencetak sarjana siap pakai dan mampu beradaptasi dengan perkembangan teknologi yang terjadi. Aktivitas pembelajaran di lembaga-lembaga pendidikan tinggi tidak hanya difokuskan pada upaya mendapatkan pengetahuan secara teori sebanyakbanyaknya, melainkan juga harus mampu memanfaatkan perkembangan teknologi guna meningkatkan kualitas pembelajaran. Peningkatan kualitas pembelajaran diharapkan akan dapat menciptakan kemampuan profesional di bidang tertentu yang sangat penting artinya bagi pelajar dan masa depannya. Namun perkembangan teknologi yang semakin meningkat dari waktu - kewaktu menuntut semakin kompleksnya akan pemahaman kombinasi dari bidang ilmu dan perkembangan teknologi yang menyertainya.

Perkembangan teknologi telah merambah berbagai aspek kehidupan, tidak terkecuali dalam bidang akuntansi. ditambah lagi system informasi yang semakin tidak terbatas termasuk Information and Communication Technology (ICT) yang telah melenyapkan keterbatasan jarak dalam penyelesaian kasus-kasus akuntansi. Sarjana akuntansi diharapkan sudah dapat memanfaatkan perkembangan teknologi ini dengan mengkombinasikannya dengan bidang akuntansi. Namun usaha tersebut tidaklah semudah yang dikira. Banyak hal yang mesti disiapkan mulai dari ketersiapan dosen, fasilitas, perangkat dan media pembelajaran, termasuk kesiapan peserta didik dalam menguasai kombinasi perkembangan ilmu pengetahuan dan teknologi ditambah lagi kemampuan mengkaitkannya dengan permasalahan riil akuntansi yang terjadi di dunia usaha.

Berdasarkan hasil penelitian maka ada beberapa hal yang dapat dibahas dalam penelitian ini diantaranya terkait dengan isu tentang masalah pentingnya penelitian ini dilakukan adalah dapat dilihat dari kontribusi positif terhadap dunia pendidikan terutama di dalam menyiapkan tenaga professional di bidang akuntansi khususnya dalam menyiapkan tenaga siap pakai yang mampu mengkombinasikan perkembangan ilmu pengetahuan dengan perkembangan teknologi. Bila lebih diditailkan lagi maka kontribusi ini bisa meliputi; (1) Kontribusi dalam menunjang pembangunan bidang pendidikan dan (2) Kontribusi bagi pengembangan institusi, khususnya dalam rangka ikut berperan dalam pengembangan ilmu pengetahuan dan teknologi.

Produk penelitian ini berupa perangkat visualisasi sistem akuntansi yang menggambarkan bagaimana sistem akuntansi suatu perusahaan dengan berbasis kasus-kasus akuntansi. Dalam 
perangkat visualisasi ini elemen- elemen pembentuk sistem akuntansi diprioritaskan dalam hal penyajiannya diantara elemenelemen tersebut diataranya: formulir, Jurnal, buku besar, buku besar pembantu dan laporan keuangan. Kelima komponen pembentuk sistem ini dituangkan dalam perangkat visualisasi. Perangcangan perangkat visualisasi sistem akuntansi di tahun kedua sudah mengalami penyempurnaan penambahan materi akuntansi bila dibandingkan dengan produk di tahun pertama. Produk penelitian ini juga sudah mulai diuji coba dalam pembelajaran untuk memperoleh respon peserta kuliah dan penyempurnaan substansi.

Terkait dengan temuan penelitian ditahun kedua terfokus pada kepuasan pengguna dalam perkuliahan secara general dapat disimpulkan bahwa sebanyak 31,4\% peserta kuliah/responden merasa sangat puas dengan produk penelitian, sebagian besar peserta kuliah atau $61,6 \%$ merasa puas dengan pemanfaat perangkat visualisasi namun masih ada peserta sebanyak $7,1 \%$ merasa kurang puas dalam pemanfaatan perangkat visualisasi dalam rangka pembelajaran mata kuliah Sistem Akuntansi. Hal ini menunjukkan produk penelitian masih perlu untuk disempurnakan lagi baik dari segi substansi maupun dalam hal tampilan dan kepraktisan operasional. Terkait dengan hasil belajar secara general juga dapat disimpulkan bahwa pemahaman peserta sudah mencapai tingkat penguasaan diatas $70 \%$ keatas. (table 5.2 , table 5.3 dan table 5.4)

Berdasarkan hasil penelitian dan pembahasan maka ada beberapa hal yang dapat dijadikan implikasi penelitian diantaranya: (1) dari hasil tingkat kepuasan pengguna dan hasil belajar menunjukkan bahwa perangkat visualisasi system akuntansi masih perlu untuk disempurnakan lagi untuk pelaksanaan tahun berikutnya terutama terkait dengan: tampilan umum dan media yang digunakan, sitematika dan substansi perangkat. (2) Perangkat visualisasi yang merupakan produk penelitian sampai dengan tahun kedua ini belum di link dengan perkembangan ICT, sehingga untuk penelitian tahun berikutnya setelah secara substansi dan tampilan perangkat ini sudah dianggap cukup baik baru disempurnakan lagi menjadi perangkat visualisasi berbasis ICT.

\section{SIMPULAN DAN SARAN}

Berdasarkan dari hasil penelitian dan pembahasan maka dapat disimpulkan bahwa: (1) Perangkat visualisasi sistem akuntansi yang menjadi produk penelitian sampai dengan tahun kedua ini menggambarkan bagaimana sistem akuntansi suatu perusahaan dengan berbasis kasus-kasus akuntansi. Dalam perangkat visualisasi ini elemen- elemen pembentuk sistem akuntansi diprioritaskan dalam hal penyajiannya diantara elemenelemen tersebut diataranya: formulir, Jurnal, buku besar, buku besar pembantu dan laporan keuangan. Perancangan perangkat visualisasi sistem akuntansi sampai dengan ditahun kedua baru berupa media visualisasi yang belum di link dengan perkembangan ICT namun media ini harus diuji coba dulu dalam pembelajaran untuk memperoleh respon peserta kuliah dan penyempurnaan substansi. (2) Penelitian ditahun kedua terfokus pada kepuasan pengguna dalam perkuliahan secara general yang menunjukkan bahwa sebanyak $31,4 \%$ peserta kuliah merasa sangat puas dengan produk penelitian, sebagian besar peserta kuliah atau $61,6 \%$ merasa puas dengan pemanfaat perangkat visualisasi namun 
masih ada peserta sebanyak $7,1 \%$ merasa kurang puas dalam pemanfaatan perangkat visualisasi dalam rangka pembelajaran mata kuliah Sistem Akuntansi. Hal ini menunjukkan produk penelitian masih perlu untuk disempurnakan lagi baik dari segi substansi maupun dalam hal tampilan dan kepraktisan operasional. Terkait dengan hasil belajar secara general juga dapat disimpulkan bahwa pemahaman peserta sudah mencapai tingkat penguasaan diatas $70 \%$ keatas.

\section{DAFTAR PUSTAKA}

Albertus O. 2001, Menguasai MYOB Accounting 10 dan Time Billing. Jakarta: Elex Media Komputindo.

AL. Haryono J. 2001. Dasar - dasar Akuntansi. Jilid 1. Yogyakarta: Bagian Penerbitan STIE YKPN.

AL. Haryono J. 2001. Dasar - dasar Akuntansi, Jilid 2. Yogyakarta: Bagian Penerbitan STIE YKPN.

Arens, Alvin A, Randal J. E and Mark S. B. 2003. Auditing and Assurance Service an Integrated Approach. Ninth Edition. New Jersey: Person Education Inc.

Arens, Alvin A dan James K. L. 1994. Auditing Pendekatan Terpadu. [Adaptasi: Amir Abadi Jusuf]. Jakarta: Salemba Empat.

Arnyana. 2005. Pengaruh Penerapan Model PBL dipandu Strategi Kooperatif Terhadap Kecakapan Berfikir Kritis Siswa SMA Pada Mata Pelajaran Biologi. Singaraja. Jurnal Pendidikan dan Pengajaran, 38, 646-667

Arnyana. $\quad 2006 . \quad$ Model-model Pengembangan Perangkat Pembelajaran. Singaraja. Makalah yang disampaikan dalam Lokakaraya Model-model pembelajaran Unit P3AI IKIP Negeri Singaraja

Candiasa. 2005.Teknologi Informasi Dan Komunikasi Di Sekolah Menengah Srategi Pembelajaran dan Instrumen Evaluasinya. Singaraja. Jurnal
Pendidikan Dan Pengajaran, 38 no.4, 561-577

Carspecken, P.F. 1996. Critical Etnography in Educational Research. A Theoritical and Practical Guides. NY and London: Routledge.

Cooper. 1990. The implementation of moral paradigm in our education. KanadaNew Jersey: Bacon, Ltd.

Degeng, N.S. 2003. Bisa Ciptakan Bangsa Buruh, Jawa Post. HIm.30.

Direktorat Pembinaan Pendidikan Tenaga Kependidikan. 2006. Pedoman Penyusunan Usulan dan Laporan Penelitian Untuk Peningkatan Kualitas Pembelajaran Di LPTK (PPKP). Jakarta: Departemen Pendidikan Nasional

Gagne, R M.; Briggs, Leslie J.; dan Wager, Walter W. 1988. Principles of Instructional Design. 3rd. Edition, New York: Holt Rinehart and Winston, Inc..

Galbreath,J. 1999. Preparing the 21 Century Worker: The Link Between ComputerBased Tecnology And Future Skill Sets. Educational Technology. Desember 1999

Gijselaers, W.H. (1996). Connecting Problem-Based Practices with Educational Theory. New Direction for Teaching and Learning. No.68.

Hansen, M. 2004. Management Accounting. Jakarta: Salemba Empat

Hendriksen, E.S. (Marianus Sinaga, Editor). 1996. Teori Akuntansi. Edisi ke- 4. Jakarta: Erlangga.

Hendriksen, V.B. 2000. Teori Akunting. Edisi Kelima. Batam: Penerbit Interaksa

Ibrahim, M. 2001. Model Pengembangan Perangkat Pembelajaran Menurut Kemp \& Thiagarajan. Surabaya: Universitas Negeri Surabaya

Ibrahim,M. dan Nur, Moh. 2004. Pengajaran Berbasis Masalah. Surabaya: University Press.

Ikatan Akuntan Indonesia. 2002. Standar Akuntansi Keuangan. Jakarta: Salemba Empat. 
Imam G., John C. 2002. Statistik Non Parametrik. Semarang: Badan Penerbit Universitas Diponegoro

Imam G. A. C,. 2003. Teori Akuntansi. Edisi Revisi, Semarang: Badan penerbit Universitas Diponegoro

Johar A. 2000. M.Y.O.B Accounting Plus 9.x dan V.10. Jakarta: Elex Media Komputindo

Johar A. 2000. Trik Akuntansi dengan Dac Easy Accounting \& MYOB Accounting. Jakarta: Elex Media Komputindo.

Johar A. 2001. Mengupas tuntas MYOB Accounting Multi Currency. Jakarta: Elex Media Komputindo

Johar A. 2004. Aplikasi Excel Dalam Studi Akuntansi dan Manajemen Keuangan. Jakarta: Elex Media Komputindo.

Johnson. 2002. Joining Together: The Principles of Cooperative Learning. USA: Open University Press.

Johnson, E.B. 2002. Contextual Teching and Learning. California: Corwin Press.

Joyce, Bruce and Marsha Weil. 1986. Models of Teaching. (Third Edition). Englewood Cliffs. N.J.: Prentice-Hall, Inc.

Kagan, R.H and James B. 1999. Learning Revolution: New Paradigm in Teaching Secondary Students. Jornal of Education. No.101. Vol. 10 January 2000. http://kagan.olam.asu.edu/epaa

Kam, V. 1990. Accounting Theory. Second Edition. John Wiley and Sons Inc.

Keiso, Donald E dan Weygad, Jerry J. (1995). Intermediate Accounting. Edisi ke-10 Jakarta: Penerbit Erlangga.

Knirk, F.G and Gustafon, K.L. 1986. Instructional Technology: A Systematic Approach To Education. New York: CBS College Publishing

Kusnadi, Lukman S., Kertahadi. 2001. Teori Akuntansi. Malang: Universitas Brawijaya

Mulyadi. 1997. Sistem Informasi Akuntansi. Yogyakarta: BPFE
Mulyasa. 2003. Kurikulum Berbasis Kompetensi; Konsep, Karakteristik, dan Implementasi. Bandung: Remaja Rosdakarya.

Puskur. (2003). Kurikulum Berbasis Kelas. Avalailable at: http/www: info@puskur.or.id, blitbang@cbn.net.id

Puskur. 2003. Otonomi Pendidikan dan Kurikulum Berbasis Kelas. Avalailable at: http/www: info@puskur.or.id, blitbang@cbn.net.id

Puskur. 2003. Pengelolaan Kurikulum Berbasis Kelas. Avalailable at: http/www:_info@puskur.or.id, blitbang@cbn.net.id

Rahyuda, Nurcaya. 1999. Pengantar Aplikasi Komputer. Denpasar: Fakultas Ekonomi Universitas Udayana.

Ratna, W.D. 1996. Teori-Teori Belajar. Jakarta: Erlangga

Ricard I. A. 2006. Learning to teach with online Learning Center Card With Power Web and CR-ROM: Mc. Graw Hill

Rindell, A.J.A.1999. Appying Inquiry-Based dan Cooperative Group Learning Strategies to Promote Critical Thinking. Journal Of College Science Teaching (JCST). 28(3): 203-207

Siti,M. dan Suheimi, S. 2005. Implementasi Pembelajaran Kontektual Melalui Model Pembelajaran Kooperatif berbantuan Buku Ajar Untuk Meningkatkan Aktivitas dan Hasil Belajar Kimia Dasar Mahasiswa Jurusan IImu Keolahragaan. Singaraja. Jurnal Pendidikan Dan Pengajaran, 38 no.3, 397-418

Soemarso S.R. 1999. Akuntansi Suatu Pengantar , Buku satu. Jakarta: Rineka Cipta.

Soemarso S.R. 1999. Akuntansi Suatu Pengantar. Buku dua. Jakarta: Rineka Cipta

Sugiyono, Eri W. 2004. Statistika untuk Penelitian. Jakarta: Alfabeta

Jurnal Pendidikan Indonesia | 63 
Suharsono, N. 1991. Model Pembelajaran Pemecahan Masalah: Penerapan di Bidang Bisnis. Disertasi tidak diterbitkan. Program Pascasarjana IKIP Malang.

Suharsono, N., Ketut Rindjin, Made Japa. (1994). Respons dan Tindakan Mahasiswa di Kelas. Studi Eksploratoris di STKIP Singaraja. Laporan Hasil Penelitian. tidak diterbitkan.

Suharsono, N . 1998. Penerapan Model Pembelajaran Pemecahan Masalah untuk Mengembangkan Kemampuan Berpikir dan Bernalar Mahasiswa. Singaraja. Laporan Hasil Penelitian, tidak diterbitkan.

Sutrisno, H. 2004. Metodelogi Research. Yogyakarta: Penerbit Andi

UNESCO. 1996. What Makes a Good Teacher? Children Speak Their Minds. Paris.

UNESCO. 1998. World Education Reports: Teachers and Teaching in a Changing World. Paris.

Universitas Pendidikan Ganesha Singaraja. 2006. Profil Jurusan Akuntansi. Singaraja.

Universitas Pendidikan Ganesha Singaraja. 2004. Buku Pedoman Studi Tahun 2002. Edisi Revisi. Singaraja. 